\title{
Long-acting injectable antipsychotics (LAls) for maintenance treatment of bipolar and schizoaffective disorders: A systematic review
}

\author{
Isabella Pacchiarotti ${ }^{a}$, Jari Tiihonen ${ }^{b, c}$, Georgios D. Kotzalidis ${ }^{d}$, \\ Norma Verdolini ${ }^{a, e, f}$, Andrea Murru ${ }^{a}$, José Manuel Goikolea ${ }^{a}$, \\ Marc Valentía ${ }^{a}$ Alberto Aedo ${ }^{a, g}$, Eduard Vieta ${ }^{a, *}$
}

\footnotetext{
a Barcelona Bipolar Disorders Program, Hospital Clinic, Institute of Neuroscience, University of Barcelona, IDIBAPS, CIBERSAM, 170 Villarroel st., Barcelona, Catalunya, Spain

${ }^{\mathrm{b}}$ Department of Forensic Psychiatry, University of Eastern Finland, Niuvanniemi Hospital, Kuopio, Finland

'Department of Clinical Neuroscience, Karolinska Institutet, Stockholm, Sweden

${ }^{\mathrm{d}}$ Neurosciences, Mental Health, and Sensory Organs (NESMOS) Department, Faculty of Medicine and

Psychology, Sapienza University, Sant'Andrea Hospital, Rome, Italy

e FIDMAG Germanes Hospitalàries Research Foundation, Sant Boi de Llobregat, Barcelona, Catalunya, Spain

${ }^{\mathrm{f}}$ Division of Psychiatry, Clinical Psychology and Rehabilitation, Department of Medicine, Santa Maria della Misericordia Hospital, University of Perugia, Perugia, Italy

¿ Unidad de Trastorno Afectivo Bipolar, Departamento de Psiquiatría, Escuela de Medicina, Pontificia

Universidad Católica de Chile, Santiago, Chile
}

Received 16 November 2018; received in revised form 9 January 2019; accepted 2 February 2019

Available online $x x x$

\section{KEYWORDS}

Bipolar disorder;

Schizoaffective

disorder;

\begin{abstract}
Long-Acting Injectable Antipsychotics (LAls) are used to overcome non-compliance in psychoses, mainly schizophrenia spectrum disorders. We aimed to summarize available evidence of studies comparing the efficacy of LAls to placebo or oral medications for Bipolar Disorder
\end{abstract}

\footnotetext{
* Corresponding author.

E-mail addresses: evieta@clinic.cat, evieta@clinic.ub.es, jsanche1@clinic.ub.es (E. Vieta).
} 
I. Pacchiarotti, J. Tiihonen and G.D. Kotzalidis et al.

Long-acting injectable antipsychotic treatment; Risperidone long-acting; Paliperidone palmitate long-acting injectable; Aripiprazole monohydrate long-acting injectable
(BD) and/or Schizoaffective Disorder (SAD). We searched six databases from inception to 28March-2018, using the strategy: long-acting antipsychotics AND (bipolar disorder OR schizoaffective disorder $O R$ mania $O R$ manic $O R$ bipolar depression). We included peer-reviewed double-blind comparisons of LAls for any clinical outcome occurrence in BD, or open mirror studies with same prospective as retrospective assessment periods. We excluded studies reporting on mixed schizophrenia/SAD populations without reporting results separately. The pooled records amounted to 642. After duplicate removal and inclusion/exclusion criteria application, we included 15 studies, 6 double-blind and 9 open, 13 assessing BD and 2 SAD. Depot neuroleptics prevented manic, but not depressive recurrences and may worsen depressive symptoms. Risperidone long-acting injectable was found to be effective in protecting from any $\mathrm{mood} /$ manic symptom compared to placebo, but not from depressive recurrences. Add-on or monotherapy paliperidone palmitate in SAD patients protected from psychotic, depressive, and manic symptoms. In patients with BD-I with a manic episode at study enrolment, aripiprazole monohydrate significantly delayed time to recurrence of manic episodes without inducing depressive episodes. LAls are effective and well-tolerated maintenance treatments for BD and SAD. They showed better efficacy in preventing mania than depression. LAls may be first-line for BD-I and SAD patients with a manic predominant polarity and with non-adherence problems. (C) 2019 Published by Elsevier B.V.

\section{Introduction}

Bipolar Disorder (BD) is a severe, recurrent and disabling mood disorder characterised by manic, hypomanic or mixed episodes, and alternating episodes of depression that affects approximately $2 \%$ of worldwide population (Grande et al., 2016). Affective episodes are recurrent and commonly associated with unfavorable outcomes, including poorer cognitive performance and greater number of hospitalizations (Vieta et al., 2018). BD is typically associated with high mortality due mostly to cardiovascular diseases and an increased risk of suicide (Kendall et al., 2014; Kishi et al., 2016; Vieta et al., 2018). Moreover, BD is often associated with persistent symptoms leading to social and functional impairment (Martinez-Aran et al., 2009; Bortolato et al., 2015; Solé et al., 2018). Due to the chronic nature of the disorder and the negative consequences of unremitted or recurrent symptoms, BD requires long-term maintenance therapy to prevent future mood episodes as the primary goal of treatment after treating an acute affective episode. Despite lithium remains the gold standard prophylactic treatment for BD (Nivoli et al., 2010), patients may not accept lithium due to various reasons including monitoring requirement, side effects or poor adherence to treatment (Murru et al., 2012, 2013). Thus, many patients require alternative prophylactic treatment for BD. Multiple studies and most BD treatment guidelines (Derry and Moore, 2007; Goodwin GM and Consensus Group of the British Association for Psychopharmacology, 2009; Grunze et al., 2013; National Collaborating Centre for Mental Health (UK), 2018; Yatham et al., 2018) recommend the use of oral secondgeneration antipsychotics (SGAs) as a long-term option for BD and many SGAs have official European Medical Agency (EMA) approval for this indication.

Similarly, schizoaffective disorder (SAD) is a chronic and severe illness consisting on the concurrent presentation of symptoms of schizophrenia and affective disorders (depression and/or mania) (Murru et al., 2016). Actually, there is a still unresolved debate on nosological distinctions among schizoaffective disorder (SAD), BD-I with psychotic features and schizophrenia (SZ) (Tondo et al., 2016).

Adherence to medication is essential for BD and SAD patients to respond satisfactorily to treatment. Nonetheless, the frequency of nonadherence in BD and SAD patients bipolar type is estimated to range between $10 \%$ and $60 \%(9,10,18)$ even during euthymic periods (Colom et al., 2000). Nonadherence increases the risk of relapse and suicide (Samalin et al., 2014) as well as the risk of rehospitalization (Gigante et al., 2012). It should be stressed that despite patients' will to receive LAl treatment, this type of treatment is still less used in patients discharged after hospitalization for a psychotic episode (Hamann et al., 2014), even if their long-term safety has been demonstrated (Lindenmayer et al., 2007).

Long-acting injectable (LAls) antipsychotics, including first-generation depot antipsychotics (FGDAs) and secondgeneration depot antipsychotics (SGDAs) may improve treatment adherence in patients with psychiatric illness requiring long-term maintenance treatment (Gigante et al., 2012; Llorca et al., 2013). LAls have been shown to decrease the rate of relapse and hospitalization in patients with schizophrenia (Correll et al., 2016). The use of LAls in the maintenance treatment of $B D$ and $S A D$ has raised interest for improving adherence and reducing the risk of relapse (Gigante et al., 2012; Samalin et al., 2014; Kishi et al., 2016). In a recent, large population-based observational cohort effectiveness study $(N=18,018)$ based on the Finish registry of the whole population of Finland (Lähteenvuo et al., 2018), the most effective treatments to prevent re-hospitalization in BD patients were lithium and LAls, with $30 \%$ of rehospitalization risk reduction with LAls compared to the same medications in oral formulations. To date, FDA has approved the use of risperidoneLAI (RIS-LAI) as both monotherapy and as adjunct therapy to lithium and valproate for the maintenance treatment of BD-I. Recently, FDA has approved aripiprazole monohydrate extended-release injectable suspension (Ari-M) for the maintenance monotherapy treatment of BD-I. RIS-LAI 
and recently paliperidone palmitate $(\mathrm{Pal}-\mathrm{P})$ have received EMA indication for SAD disorder. On the contrary, no LAI has current EMA indication for BD. Although FGDAs have been studied in BD, they have not been approved for use in this disorder (Gigante et al., 2012).

To summarize the available evidence, we conducted a systematic review of studies comparing the efficacy and safety of first- and second-generation depot antipsychotics (FGDAs and SGDAs, respectively) to placebo (PBO) or oral medications for $B D$ and $S A D$. We decided to include in this review also $S A D$ due to the similarities in acute and longterm need for treatments aimed at manic, mixed, depressive polarities, both psychotic and nonpsychotic, that justify a conceptual framework of continuity across these two conditions (Murru et al., 2016; Argolo et al., 2018).

\section{Procedures}

This review has been conducted according to the PRISMA (Preferred Reporting Items for Systematic Reviews and Meta-Analyses) statement (Moher et al., 2009). Search Methods and Results are highlighted in Fig. 1.

\subsection{Literature search}

We systematically searched the MEDLINE/PubMed/Index Medicus, Cochrane Library, CINHAL, PsycINFO/PsycARTICLES, clinicaltrials.gov, and Scopus databases from any time to 28 March 2018, cross-checking the obtained references. The systematic search was performed by two blind independent research teams (led by IP and GDK), searching as follows:

- MEDLINE/Pubmed/Index Medicus: authors used the following search strategy: (depot OR once-monthly OR 3month* OR long-acting OR LAI[ti] OR LAls[ti] OR monohydrate OR lauroxil OR palmitate OR pamoate OR microsphere* OR dodecanoate OR decanoate OR enanthate OR oenanthate OR acetate OR consta OR maintena OR zypadhera OR xeplion OR sustenna OR trinza) AND (aripiprazole OR olanzapine OR risperidone OR paliperidone OR risperdal OR 9-OH-risperidone OR 9hydroxyrisperidone OR haloperidol OR fluphenazine $O R$ flupentixol OR flupenthixol OR zuclopenthixol OR pipothiazine) AND (bipolar disorder OR bipolar depression OR mania OR manic OR schizoaffective) that produced 374 records. Of them, duplicates were 0 , and selected for analysis 13 .

- For the Cochrane library we used the same search strategy, save for the use of square brackets, that the database's system does not accept; the search produced 144 records, one of which unlocalisable. It added no includible record to the PubMed search.

- With the other databases we performed the same search as for PubMed. CINHAL yielded 92 records.

- PsycINFO/PsycARTICLES yielded 365 records.

- Scopus produced 37 records.

- For the https://clinicaltrials.gov/ database, keywords were: long-acting antipsychotics AND bipolar disorder OR schizoaffective disorder and produced 29 records. Of all databases used and the additional 15 records that were identified through other sources/reference lists, none added an includible article to the pool of records identified by and selected from PubMed.

\subsection{Study selection}

We included longitudinal studies of the effect of LAls in the treatment of patients with BD and SAD. Studies could be experimental (randomized clinical trials (RCT), quasi-RCTs, nonRCTs), quasi-experimental (controlled before and after studies, interrupted time series), and observational (cohort, case-control, registry studies). We excluded animal studies, and studies resulting from databases but not being relevant as to the effects of the administration of LAl antipsychotics in patients with BD or SAD. Excluded were also studies on the effects of LAls on mixed schizophrenia/schizoaffective disorder patients without reporting results separately. Metaanalyses and reviews were used as evidence to support information that could not be drawn from individual studies. Open studies, unless they had a mirror design with a retrospective period equal to the longitudinal prospective one, case reports or series, pharmacoeconomy studies not providing clinical outcomes, letters to the editor, author responses to criticisms, opinion papers, editorials, studies focusing only on biomarkers, like genetic investigations and brain imaging, pharmacokinetic studies, technical studies focusing on types of formulations or study designs, were excluded. Congress Abstracts, despite not being subjected to peer reviewing, were considered if they provided sufficient data for analysis and they were not subsequently published in regular papers.

For this review, we filled-in the PICO worksheet (Miller, 2001), the AMSTAR form (Shea et al., 2017), and the PRISMA checklist (Moher et al., 2009), which we provide as an online Supplementary file. We assessed the quality of included trials with Jadad's et al. (1996) scale for the evaluation of randomized control trials and the strength of our recommendations with the National Health and Medical Research Council (NHMRC) of the Australian Government's (2009) NHMRC levels of evidence and grades for recommendations for developers of guidelines. Risk of bias was addressed with taking into account the Cochrane Risk of Bias Tool (Higgins and Green, 2011), classifying each study according to a high, low, unclear category for the selection, reporting, performance, detection, attrition, and other dimensions, which then affected the global quality of the paper.

\section{Results}

\subsection{Systematic search results}

The pooled records amounted to 640 Records (Fig. 1). Excluded were: 114 Reviews, 113 NBSA, 77 No LAI, 65 Open (open design-no mirror), 130 Case (reports/series), 0 Inadeq (inadequate design or outcomes), $33 \mathrm{E} / \mathrm{O}$ (editorials/opinion papers), $13 \mathrm{PhEc}$ (Pharmacoeconomic studies), 14 Surveys, 1 Biotech (biotechnologies, laboratory), 15 PhK (pharmacokinetics), 12 BM/Gen (biomarkers, brain imaging, 


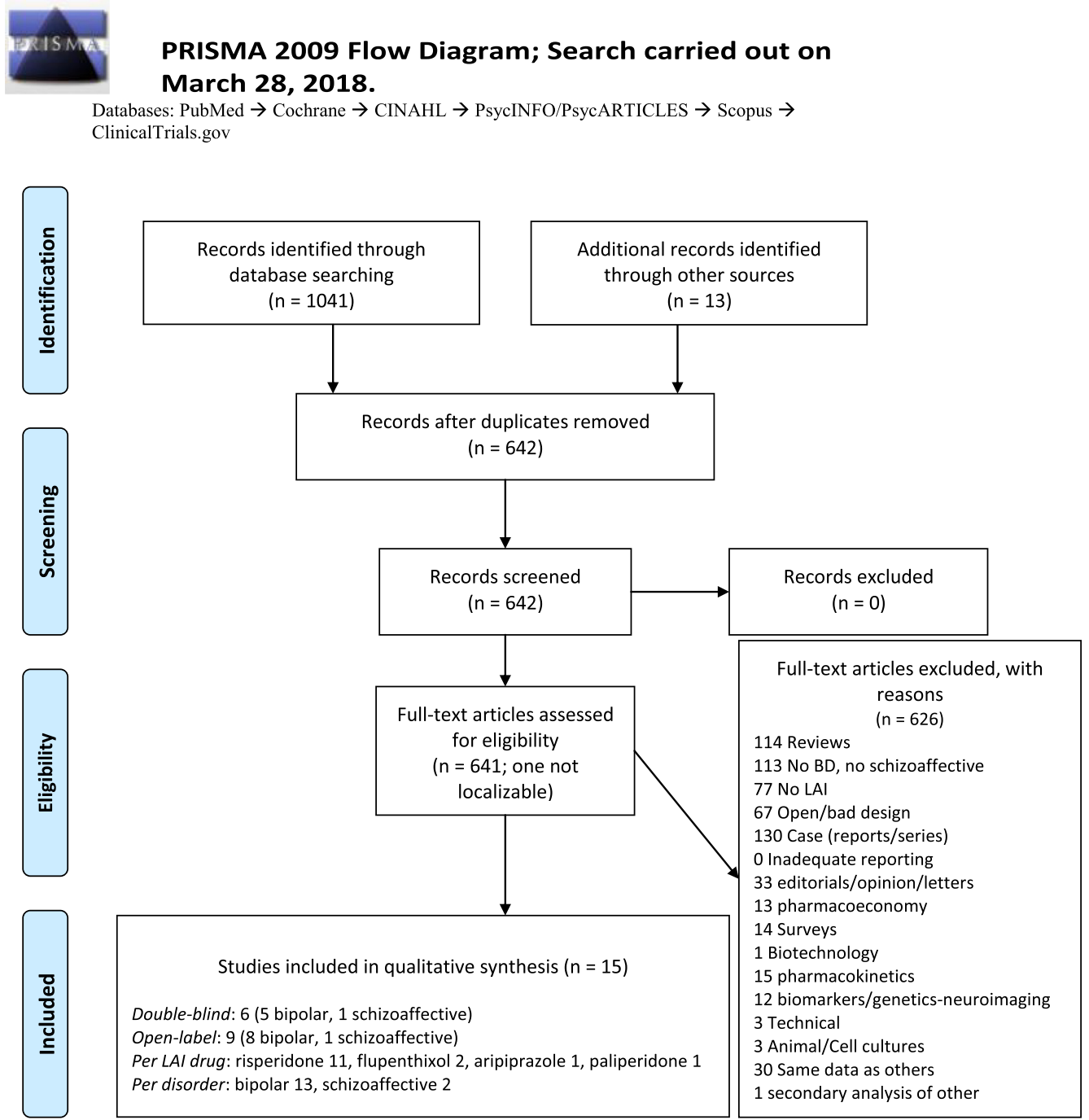

Fig. 1 PRISMA flow diagram and results of our literature search, including reasons for exclusion and typology of included studies. From Moher et al. (2009) www.prisma-statement.org.

or genetics), 3 Technical, 3 Animal/Cell (studies on nonhumans or on isolated cell tissues), 1 was a secondary analysis of the data of another study that had changed the primary outcome to a part of the primary outcome of the other (i.e., time to hospitalization instead of time to recurrence, which was defined in part also by hospitalization) and 30 Same (reporting data elsewhere published better). 1 was not possible to localize. This left 15 records to include (Fig. 1). We included 6 double-blind studies and 9 open studies. 13 studies assessed BD and 2 SAD. One trial tested aripiprazole monohydrate once monthly (double-blind, BD); 2 trials assessed the use of flupenthixol depot (1 double-blind, 1 open, BD); 1 trial tested paliperidone palmitate (double-blind, SAD); 11 trials assessed RIS-LAI (8 open-3 double-blind, 10 BD-1 SAD). The details of each study are reported in Table 1.

Most studies were of good to satisfactory quality of evidence, but none was excellent, despite some studies had included large samples (Table 1). Reasons varied, with all multisite studies not addressing intersite variability issues, high rate of attrition bias, not clearly disclosed method of randomization, small samples, and possible sponsor bias.
Hence, the total strength of recommendations of this review according to the National Health and Medical Research Council (NHMRC) (2009) is from satisfactory to good.

\subsection{Content results}

\subsubsection{First-generation depot antipsychotics (FGDA)}

Two studies have been included regarding the use of flupenthixol depot in BD patients as alternative to lithium. The first (Ahlfors et al., 1981) was a non-blind, randomized study with flupenthixol decanoate vs. lithium in $33 \mathrm{BD}$ patients who had experienced at least three manic or depressive episodes during the last 5 years before the enrolment. The results showed no differences in terms of number of episodes per year and in time spent ill between the two groups. Also comparing the 5 years pre-trial, neither flupenthixol nor lithium showed significant prophylactic effect against mood episodes. In the second RCT study (Esparon et al., 1986), 15 patients were randomized to flupenthixol $20 \mathrm{mg} / \mathrm{month}$ or PBO as adjunctive treatment to lithium. No 
Table 1 Summary of included studies in reverse chronological order, their quality/risk of bias assessment, and their typology.

\begin{tabular}{|c|c|c|c|c|c|c|}
\hline $\begin{array}{l}\text { Studies by first } \\
\text { author and } \\
\text { date in reverse } \\
\text { order }\end{array}$ & Study design & $\begin{array}{l}\text { Population, } n \\
\text { (sites; sp. Y/N) }\end{array}$ & Duration & Drug & Main outcomes & $\begin{array}{l}\text { Quality } \\
\text { (includes } \\
\text { bias) }\end{array}$ \\
\hline $\begin{array}{l}\text { Hsieh et al. } \\
\text { (2017) }\end{array}$ & $\begin{array}{l}\text { Open RIS-LAI mirror } \\
\text { (BD, rapid and } \\
\text { non-rapid cycling } \\
\text { stratification was } \\
\text { performed) }\end{array}$ & $\begin{array}{l}287,251 \\
\text { noncycling, } 36 \\
\text { rapid cycling } \\
\text { (National } \\
\text { database; N) }\end{array}$ & 12 months & $\begin{array}{l}\text { RIS-LAI (mean } \\
\text { dose: } 24.6 \\
\text { mg/2weeks) as } \\
\text { add-on to TAU } \\
\text { during } 1 \text { year } \\
(n=287)\end{array}$ & $\begin{array}{l}\text { - The prevalence of } \\
\text { concomitant use of TAU } \\
\text { decreased from the } \\
\text { pre-RIS-LAI period to the } \\
\text { post-RIS-LAI period } \\
\text { - RIS-LAI use decreased } \\
\text { emergency room (ER) visits, } \\
\text { hospital admissions, length } \\
\text { of hospital stay, and } \\
\text { non-medication costs } \\
\text { - RIS-LAl use decreased the } \\
\text { number of change-in-mood } \\
\text { episodes in rapid cycling } \\
\text { patients }\end{array}$ & 2 \\
\hline $\begin{array}{l}\text { Calabrese } \\
\text { et al. (2017) }\end{array}$ & $\begin{array}{l}\text { DB Ari-M vs. PBO } \\
\text { withdrawal surv } \\
\text { (BD-I) }\end{array}$ & $\begin{array}{l}266(103,7 \\
\text { countries in } 3 \\
\text { continents; Y) }\end{array}$ & 52 weeks & $\begin{array}{l}\text { Ari-M }(400 \mathrm{mg} / 1 \\
\text { month })(n=133 \\
\text { completers }=64) \\
\text { vs. PBO }(n=133 \text {, } \\
\text { completers }=38)\end{array}$ & $\begin{array}{l}\text { - Time to recurrence of any } \\
\text { mood episode: Ari > PBO } \\
\text { - Rates of recurrences of } \\
\text { any mood episode: } \\
\text { Ari < PBO } \\
\text { - Effects observed } \\
\text { predominantly on manic } \\
\text { episodes }\end{array}$ & $3^{a}$ \\
\hline $\begin{array}{l}\text { Chan et al. } \\
(2016)\end{array}$ & $\begin{array}{l}\text { Open RIS-LAI mirror } \\
\text { (BD-I) pre- and post-1 } \\
\text { year RIS-LAI }\end{array}$ & $469(1 ; N)$ & 12 months & $\begin{array}{l}\text { RIS-LAI +TAU ( } 2 \\
\text { groups, compliant } \\
\text { and non-compliant } \\
n=77) \text { vs. } \\
\text { SGA+TAU ( } 2 \\
\text { groups NRIS-LAI, } \\
\text { compliant and } \\
\text { non-compliant } \\
n=392)\end{array}$ & $\begin{array}{l}\text { - Re-hospitalization rates } \\
\text { were significantly lower in } \\
\text { the post RIS-LAl1 group than } \\
\text { pre-RIS-LAI period for any } \\
\text { mood episode, manic and } \\
\text { depressive episodes } \\
\text { - Rates of emergency room } \\
\text { visit were significantly } \\
\text { lower in the RIS-LAI1, } \\
\text { RIS-LAI2 and NRIS-LAI1 } \\
\text { groups compared with those } \\
\text { before enrollment }\end{array}$ & 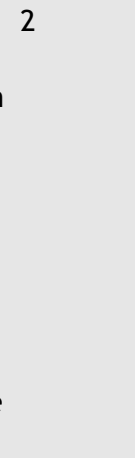 \\
\hline $\begin{array}{l}\text { Fu et al. } \\
(2015)\end{array}$ & $\begin{array}{l}\text { DB Pal-P vs. PBO surv } \\
\text { (SAD) }\end{array}$ & $\begin{array}{l}334(84,8 \\
\text { countries in } 4 \\
\text { continents; } Y)\end{array}$ & 15 months & $\begin{array}{l}\text { Pal-P once } \\
\text { monthly + TAU or } \\
\text { monotherapy (SAD } \\
n=164) \text { vs. } \\
\text { PBO+TAU (SAD } \\
n=170)\end{array}$ & $\begin{array}{l}\text { - Time to relapse for } \\
\text { psychotic, depressive, and } \\
\text { manic symptoms: Pal-P in } \\
\text { add-on or } \\
\text { monotherapy > PBO } \\
\text { - Overall relapses rates: } \\
\text { Pal-P in add-on or } \\
\text { monotherapy < PBO } \\
\text { - Relapse risk: } 2.49 \text { times } \\
\text { greater for PBO than for } \\
\text { Pal-P }\end{array}$ & 3 \\
\hline $\begin{array}{l}\text { Vieta et al. } \\
(2012)\end{array}$ & $\begin{array}{l}\text { DB RIS-LAI vs. PBO } \\
\text { surv (BD-I) }\end{array}$ & $\begin{array}{l}398 \text { (34 in } 4 \\
\text { continents; } Y \text { ) }\end{array}$ & 18 months & $\begin{array}{l}\text { RIS-LAI }(22,37.5 \\
\text { or } 50 \mathrm{mg} / 2 \text { weeks, } \\
n=132) \text { vs. PBO } \\
(n=135) \text { vs. third } \\
\text { arm Ola }(10 \mathrm{mg} / \mathrm{d}) \\
(n=131)\end{array}$ & $\begin{array}{l}\text { - Time to recurrence of any } \\
\text { mood episode: RIS-LAI > PBO } \\
\text { - Time to recurrence of } \\
\text { manic episodes: } \\
\text { RIS-LAI > PBO } \\
\text { - Time to recurrence of } \\
\text { depressive episodes: } \\
\text { RIS-LAI = PBO }\end{array}$ & $3^{a}$ \\
\hline
\end{tabular}


Table 1 (continued)

Studies by first Study design author and date in reverse order
Population, $n$ Duration Drug Main outcomes

(sites; sp. $\mathrm{Y} / \mathrm{N}$ )
Quality

(includes

bias)

\begin{tabular}{|c|c|c|c|c|c|c|}
\hline $\begin{array}{l}\text { Bobo et al. } \\
(2011)\end{array}$ & $\begin{array}{l}\text { Open, randomized } \\
\text { RIS-LAI (BD-I and II } \\
\text { rapid cycling) }\end{array}$ & $50(1 ; Y)$ & 12 months & $\begin{array}{l}\text { RIS-LAI }+ \text { TAU } \\
(n=25) \text { vs. TAU } \\
(n=25)\end{array}$ & $\begin{array}{l}\text { Rates of any-cause relapse } \\
\text { events: RIS-LAI + TAU = TAU } \\
\text { Duration of relapse events } \\
\text { (any cause): } \\
\text { RIS-LAI + TAU = TAU }\end{array}$ & $3-4$ \\
\hline $\begin{array}{l}\text { Chengappa } \\
\text { et al. (2010) }\end{array}$ & $\begin{array}{l}\text { Open, randomized } \\
\text { RIS-LAI vs. oral (BD-I } \\
\text { and II) }\end{array}$ & $48(3 ; Y)$ & 15 months & $\begin{array}{l}\text { RIS-LAI }(25,37.5 \\
\text { or } 50 \mathrm{mg} / 2 \\
\text { weeks) + TAU } \\
(\mathrm{n}=25) \text { vs. SGA } \\
\text { (Ari, Ola, Que } \\
\text { Zip) + TAU } \\
(\mathrm{n}=25)\end{array}$ & $\begin{array}{l}\text { Number of negative clinical } \\
\text { events: RIS-LAI+TAU < } \\
\text { SGA+TAU }\end{array}$ & 3 \\
\hline $\begin{array}{l}\text { Quiroz et al. } \\
(2010)\end{array}$ & $\begin{array}{l}\text { DB RIS-LAI vs. PBO, } \\
\text { surv (BD-I) }\end{array}$ & $\begin{array}{l}303(57,10 \\
\text { countries in } 3 \\
\text { continents; } Y)\end{array}$ & 24 months & $\begin{array}{l}\text { RIS-LAI }(12.5,25 \\
37.5 \text { or } 50 \mathrm{mg} / 2 \\
\text { weeks }(n=154) \\
\text { vs. PBO }(n=149)\end{array}$ & $\begin{array}{l}\text { Time to recurrence: } \\
\text { RIS-LAI>PBO (significant } \\
\text { differences for elevated } \\
\text { mood episodes but no for } \\
\text { depressive episodes) }\end{array}$ & 2 \\
\hline $\begin{array}{l}\text { Peuskens et al. } \\
\text { (2010) }\end{array}$ & $\begin{array}{l}\text { Open RIS-LAI discont. } \\
\text { SAD vs. schizophrenia }\end{array}$ & $\begin{array}{l}1659 \text { (6 } \\
\text { nationwide } \\
\text { databases in } 2 \\
\text { continents; } Y)\end{array}$ & 24 months & $\begin{array}{l}\text { RIS-LAl completers } \\
\text { after } 2 \text {-years } \\
\text { (mean dose: } \\
42.3 \mathrm{mg} / 2 \text { weeks) } \\
\text { (SDA } n=171 \text { ) vs } \\
\text { RIS-LAl } \\
\text { discontinuers after } \\
2 \text { years (mean } \\
\text { dose: } 48.8 \mathrm{mg} / 2 \\
\text { weeks) (SDA } \\
n=32 \text { ) }\end{array}$ & $\begin{array}{l}\text { Compared to the pre-RLAI } \\
\text { initiation period, at } 12 \\
\text { months post-initiation } \\
\text { completers had greater } \\
\text { reductions than } \\
\text { discontinuers in the percent } \\
\text { of patients hospitalized and } \\
\text { in the length and number of } \\
\text { hospital stays, differences } \\
\text { that remained at } 24 \\
\text { months. }\end{array}$ & 2 \\
\hline $\begin{array}{l}\text { Macfadden } \\
\text { et al. (2009) }\end{array}$ & $\begin{array}{l}\text { DB add-on RIS-LAI } \\
\text { (BD-I and II) }\end{array}$ & $\begin{array}{l}124(32,2 \\
\text { countries from } \\
2 \text { continents; } Y)\end{array}$ & 12 months & $\begin{array}{l}\text { RIS-LAI }(25,37.5 \\
\text { or } 50 \mathrm{mg} / 2 \\
\text { weeks })+ \text { TAU } \\
(n=65) \text { vs } \\
\text { PBO + TAU } \\
(n=59)\end{array}$ & $\begin{array}{l}\text { Time to recurrence: } \\
\text { RIS-LAI + TAU > PBO + TAU }\end{array}$ & 3 \\
\hline $\begin{array}{l}\text { Vieta et al. } \\
(2008)\end{array}$ & $\begin{array}{l}\text { Open mirror RIS-LAI } \\
(B D-I)\end{array}$ & $29(1 ; N)$ & $\begin{array}{l}24 \text { months } \\
\text { (mean) }\end{array}$ & $\begin{array}{l}\text { RIS- } \\
\text { LAI + TAU }(n=29) \\
\text { (mean starting } \\
\text { dose }=34.4 \mathrm{mg} \text {, } \\
\text { mean final } \\
\text { dose }=46.4 \mathrm{mg} \text { ) }\end{array}$ & $\begin{array}{l}\text { - Decreased number of } \\
\text { hospitalizations (not due to } \\
\text { depression) } \\
\text { - Decreased average length } \\
\text { of hospitalizations per } \\
\text { patient } \\
\text { - Increased time to any } \\
\text { relapse } \\
\text { - Improvement in treatment } \\
\text { adherence }\end{array}$ & $2-3$ \\
\hline $\begin{array}{l}\text { Yatham et al. } \\
(2007)\end{array}$ & $\begin{array}{l}\text { Open, randomized } \\
\text { RIS-LAI (BD I and II) }\end{array}$ & $\begin{array}{l}49(8 \text { in } 1 \\
\text { country; } Y)\end{array}$ & 6 months & $\begin{array}{l}\text { RIS-LAI } \\
\text { ( } 25 \mathrm{mg} / 2 \text { weeks) } \\
+ \text { TAU }(n=23) \text { vs. } \\
\text { SGA (Ola, Que, } \\
\text { Ris) + TAU }(n=26)\end{array}$ & $\begin{array}{l}\text { CGI-S, YMRS and MADRS: } \\
\text { RIS-LAI + TAU = SGA + TAU }\end{array}$ & $2-3$ \\
\hline
\end{tabular}

(continued on next page) 
Table 1 (continued)

\begin{tabular}{|c|c|c|c|c|c|c|}
\hline $\begin{array}{l}\text { Studies by first } \\
\text { author and } \\
\text { date in reverse } \\
\text { order }\end{array}$ & Study design & $\begin{array}{l}\text { Population, } n \\
\text { (sites; sp. Y/N) }\end{array}$ & Duration & Drug & Main outcomes & $\begin{array}{l}\text { Quality } \\
\text { (includes } \\
\text { bias) }\end{array}$ \\
\hline $\begin{array}{l}\text { Savas et al. } \\
(2006)\end{array}$ & $\begin{array}{l}\text { Open mirror RIS-LAI } \\
(B D-I)\end{array}$ & $12(1 ; N)$ & 6 months & $\begin{array}{l}\text { RIS-LAI + TAU or } \\
\text { RIS-LAI } \\
\text { monotherapy } \\
(n=12) \\
(25-50 \mathrm{mg} / 2 \\
\text { weeks })\end{array}$ & $\begin{array}{l}\text { - RIS-LAI significantly } \\
\text { reduced the severity of } \\
\text { symptoms, and no manic or } \\
\text { depressive episodes were } \\
\text { seen in these previously } \\
\text { noncompliant patients in } \\
\text { 6-month period }\end{array}$ & 4 \\
\hline $\begin{array}{l}\text { Esparon et al. } \\
\text { (1986) }\end{array}$ & DB Flup-D (BD-I) & $11(1 ; N)$ & 12 months & $\begin{array}{l}\text { Flup-D }(20 \mathrm{mg} / 4 \\
\text { weeks }+\mathrm{Li} \\
(0.6-1.2 \mathrm{mEq} / \mathrm{L}) \\
(n=9) \text { vs } \mathrm{Li}+\mathrm{PBO} \\
(n=6)\end{array}$ & $\begin{array}{l}\text { - Total number of days spent } \\
\text { in hospital: } \\
\text { Flup-D }+\mathrm{Li}=\text { Flup-D + PBO } \\
\text { - Effects in the prophylaxis } \\
\text { of either mania or of } \\
\text { depression: } \\
\text { Flup-D + Li = Flup-D + PBO }\end{array}$ & 4 \\
\hline $\begin{array}{l}\text { Ahlfors et al. } \\
\text { (1981) }\end{array}$ & $\begin{array}{l}\text { Open randomized } \\
\text { (BD) }\end{array}$ & $\begin{array}{l}204(31,5 \\
\text { countries in } 1 \\
\text { continent; } Y)\end{array}$ & 18 months & $\begin{array}{l}\text { Flup-D }(20 \mathrm{mg} / 3 \\
\text { weeks })(n=19) \text { vs } \\
\text { Lithium }(0.8-1 \\
\text { MEq/L) }(n=14)\end{array}$ & $\begin{array}{l}\text { Group I: Mean episode } \\
\text { frequency: Flup-D }=\mathrm{Li} \\
\text { Mean\%time ill: Flup-D = Li }\end{array}$ & 3 \\
\hline
\end{tabular}

${ }^{a}$ High discontinuation/low completer rate. Abbreviations: Ari, aripiprazole; Ari-M, aripiprazole monohydrate; BD, bipolar disorder (-I. type I; -II, type II); DB, double-blind study; CGI-S, Clinical Global Impression-Severity; discont., discontinuation as outcome; Flup-D, flupenthixol decanoate; Li, lithium; MADRS, Montgomery Asberg Depression Rating Scale; $n$, number; N, no; Ola, olanzapine; Open, openlabel study; Pal-P, Paliperidone palmitate; PBO, placebo; Que, quetiapine; RIS-LAI, risperidone long-acting injectable; SAD, schizoaffective disorder; SGA, second generation antipsychotic; sp. Y/N, industry-sponsored, Yes/No; surv, survival study (Kaplan-Meyer estimates); TAU, treatment-as-usual; Y, yes; YMRS, Young Mania Rating Scale; Zip, ziprasidone. Quality assessment: 1, first rate evidence; 2, good evidence; 3, fair evidence; 4, poor evidence.

differences were found between flupenthixol and PBO in the average number of days hospitalized during the depot period. When total scores were calculated on the Affective Morbidity Index, ratings for depression were worse for the flupenthixol group, although this result was not statistically significant.

\subsubsection{Second-generation depot antipsychotics (SGDA)}

We identified eleven clinical studies that investigated RISLAI in BD or SAD patients, 1 investigating Pal-P and 1 Ari-M. These included 8 open label prospective or mirror studies and 5 RCT.

Open-Label studies and unblinded controlled trials. Savas et al. (2006) examined the charts of 12 BDI predominantly manic patients, with no substance abuse and nonadherent to oral medication who received RIS-LAI $25-50 \mathrm{mg} / 2$ weeks started during a manic or hypomanic state during 6 months either in monotherapy or in combination with a mood stabilizer. No manic or depressive episodes were observed during depot treatment. A significant reduction in Clinical Gobal Impression Scale (CGI) was found, while there were no changes in Hamilton Depression Rating Scale (HAMD) scores.

An open, randomized active comparator trial with RIS-LAI vs. oral atypical antipsychotic agents (AAP) was reported by Yatham et al. (2007) in BD I or II patients currently on one oral SGA who had Young Mania Rating Scale (YMRS) and Montgomery-Asberg Depression Rating Scale (MADRS) between 13 and 19 and CGI scores between 3 and 4 (mildly to moderately ill). Patients were randomized to receive RISLAI $25-50 \mathrm{mg} / 2$ weeks or to continue previous oral SGA during 6 months. Mood stabilizers and antidepressants were permitted. Patients on RIS-LAl but not those on oral SGAs improved significantly in CGI-S and YMRS scores at 6-month follow-up. In contrast the oral SGA group had significant reductions in Hamilton Anxiety Rating Scale (HAM-A) scores relative to baseline compared to $\mathrm{BD}$ patient treated with RIS-LAI.

Vieta et al. (2008) assessed 29 acutely manic BDI patients who had one or more previous hospitalisations for mania and with a history of non-adherence to medication in a naturalistic two-year follow-up study. Patients received 25$50 \mathrm{mg} / 2$ weeks of RIS-LAl plus a mood stabilizer and other commonly prescribed medication but no other oral antipsychotics were allowed. Outcomes were compared with a previous period of one year before initiating RIS-LAI. The authors found a significant reduction in treatment discontinuation, a decrease in the number of hospitalizations per patients, a significant decrease in hospitalisations for mania or mixed episodes with RIS-LAI. No significant decreases in hospitalization rates for depression were found. Moreover, the mean length of stay per patient significantly decreased and time to relapse to any mood episode increased. Finally, improved CGI scores and decreased aggression were found with RIS-LAI. 
Peuskens et al. (2010) assessed treatment retention (vs. discontinuation) on RIS-LAl and outcomes in schizophrenia and SAD patients for whom 24 months of follow-up data in the electronic Schizophrenia Treatment Adherence Registry (e-STAR) were available.

Data were available for 171 RIS-LAl completer vs. 32 RISLAl discontinuer SAD patients. Compared to the pre-RLAI initiation period, at 12 months post-initiation completers had greater reductions than discontinuers in the percent of patients hospitalised $(66.2 \%$ reduction vs. $29.2 \%)$ and in the length $(68 \%$ reduction vs. $0 \%)$ and number $(80.0$ vs. $14.3 \%)$ of hospital stays, differences that remained unaltered after 24 months.

In a randomised, but open-label, 15-month pilot trial assessing clinical effectiveness, Chengappa et al. (2010) assessed the efficacy of RIS-LAl compared to oral SGAs in BD-I or -ll during a manic, hypomanic or mixed episode. The study provided for a 3-month titration and stabilization phase followed by a 1-year extension phase. The results of the study showed that RLAl-treated patients experienced significantly fewer negative clinical events (47 negative clinical events were recorded in terms of outcome and other safety measures) than AAP-treated patients.

Bobo et al. (2011) compared adjunctive RIS-LAl plus treatment as usual (RLAI+TAU) in a 12-month randomised open comparison of RLAI+TAU $(N=20)$ and TAU alone $(N=25)$ in $\mathrm{BD}-\mathrm{I}$ or $-1 \mathrm{l}$ with rapid cycling course. The results showed no significant between-groups differences in the total number or duration of relapse events (any cause) or in the number of manic or depressive relapses. RIS-LAI treatment significantly reduced the need for urgent care referrals or the frequency of medication adjustments to prevent relapses.

In a retrospective cohort study, Chan et al. (2016) assessed the effect of RIS-LAl treatment on BDI patients treated with RIS-LAI and different oral SGAs and followed during 1 year. On the basis of RIS-LAI use and treatment compliance, BD patients were classified into 4 groups: compliant patients receiving RIS-LAl treatment (LAI1), noncompliant patients receiving RIS-LAI treatment (LAI2), compliant patients receiving oral medications (NLAI1) and noncompliant patients receiving oral medication (NLAI2). After 1-year of follow-up, re-hospitalization rates were significantly lower in the LAI1 group than that before enrolment for any episode (manic episodes $(p=0.005)$; depressive episodes $(p=0.002)$. Emergency room visit rates were significantly lower in the LAI1 $(p=0.0001)$, LAI2 $(p=0.013)$, and NLAl1 $(p=0.0001)$ groups, compared to the respective pre-enrolment rates.

Recently, a 1-year mirror-image naturalistic study using a national claims database (Hsieh et al., 2017) assessed RIS-LAl treatment in BD patients. Rapid and non-rapid cycling stratification was performed based on the number of change-in-mood episodes within 1 year prior to the index date. The authors found that the prevalence of concomitant use of TAU decreased from the pre-RIS-LAI period to the post-RIS-LAI period. RIS-LAI use decreased emergency room (ER) visits, hospital admissions, length of hospital stay, and non-medication costs. Moreover, RIS-LAl use decreased the number of change-in-mood episodes in rapid cycling patients.
Double-blind, randomised PBO-controlled trials. MacFadden et al. (2009) reported the results of a doubleblind randomised, PBO-controlled trial with RIS-LAI 25$50 \mathrm{mg} / 2$ week as adjunctive treatment to TAU in frequently relapsing BDI patients (who had experienced 4 or more episodes during the past year). Patients were stabilized in a 16-week open-label phase with RIS-LAl and then randomised to continue RIS-LAI $(n=65)$ or switch to PBO $(n=59)$. Both groups continued with TAU, which included mood stabilizers and other medications, but not oral antipsychotics. The results showed that the relative risk of relapse was 2.3-fold higher with PBO compared with RIS-LAl group. A significant delay in time to recurrence to any mood episode was observed with RIS-LAl. Moreover, a significant increase in YMRS scores and CGI-BP-S mania and overall scores was found in the RIS-LAl group compared with PBO, while no differences were found in MADRS scores and CGI-BP-S depression between the two groups.

A 24-month randomised, double-blind, PBO-controlled study with RIS-LAI in monotherapy was conducted by Quiroz et al. (2010) on acute manic/mixed (YMRS $\geq 20$ ) or stable (CGI-S score $\leq 3$ ) BD-I patients, but requiring change of medication to depot due to safety or tolerability concerns. Patients were excluded from the study if they had more than 4 episodes/year in the 2 years before the screening (rapid cycling). BD-I patients started on the 26-week open-label stabilization phase with RIS-LAI. During the randomisation phase, 154 patients received RIS-LAI $25-50 \mathrm{mg} / 2$ weeks and 149 PBO, with a follow-up of 24-months. Results showed a significant delay in time to relapse in the RIS-LAI group compared to PBO for any mood episode $(p<0.001)$ and lower rates of recurrence with RIS-LAI (30\% with RIS-LAI vs. $56 \%$ with PBO). RIS-LAl significantly prolonged time to discontinuation for any reason compared to PBO. Nonetheless, time to recurrence was longer for RIS-LAl group compared with PBO group only for manic/hypomanic episodes but not for depressive episodes. RIS-LAI was significantly superior in maintaining the YMRS, MADRS, and CGI-S scores than PBO.

Later, the efficacy of RIS-LAl for preventing recurrence of mood episodes in BD-I patients was evaluated in another randomized, PBO-controlled study (Vieta et al., 2012). After a 12-week open-label stabilization period with RIS-LAI $(N=560)$, patients who did not experience a recurrence entered an 18-month randomised, double-blind period with RIS-LAI $(N=132)$, PBO $(N=135)$ or with olanzapine $10 \mathrm{mg} /$ day $(N=131)$ as third treatment arm for reference and exploratory comparisons. Time to recurrence of any mood episode was significantly longer with RIS- LAI vs. PBO (log-rank test stratified by region only, $p=0.031$ ). Similarly to previous studies, differences were significant for time to recurrence of manic/hypomanic episodes $(p=0.005)$ but not depressive episodes $(p=0.655)$.

Regarding the efficacy of paliperidone palmitate (Pal-P) the only study included is a double-blind, PBO-controlled trial on SAD patients (Fu et al., 2015). SAD patients experiencing acute psychotic and depressive/manic symptoms were stabilized with Pal-P monthly as monotherapy or as adjunctive therapy to mood stabilizers or antidepressants. After an open-label stabilization period of a 13-week, flexible-dose and of a 12-week fixed-dose, patients and randomly assigned to Pal-P monthly $(N=164)$ or PBO $(N=170)$ 
in a 15-month, double-blind, relapse-prevention phase. Pal$P$ significantly delayed time to relapse for psychotic, depressive, and manic symptoms compared with PBO $(p<0.001$, log-rank test). Relapse risk was 2.49 times greater for PBO (hazard ratio $=2.49 ; 95 \% \mathrm{Cl}, 1.55$ to $3.99 ; p<0.001$ ). Moreover, Pal-P was superior to PBO in maintaining functioning as measured by the Personal and Social Performance scale $(p=0.014$, mixed-model repeated-measures analysis).

Recently, Calabrese et al. (2017) reported the results of a 52-weeks, randomized, double-blind, PBO-controlled trial on the efficacy of aripiprazole monohydrate depot (Ari-M) $400 \mathrm{mg}$ once-monthly as maintenance treatment of BD-I. BD-I patients experiencing a manic episode were stabilized sequentially on oral aripiprazole and Ari-M $400 \mathrm{mg}$ (18-26 weeks) and then were randomised to Ari-M $400 \mathrm{mg}(N=133)$ or PBO $(N=133)$ during a 52 -week follow-up period. 64 patients on Ari-M and 38 patients on PBO completed the study. Ari-M 400 significantly delayed time to recurrence of any mood episode compared with PBO $(p<0.0001)$. Significantly fewer patients $(p<0.0001)$ experienced recurrence of any mood episode with Ari-M 400 (35/132; 26.5\%) compared with PBO $(68 / 133 ; 51.1 \%)$, with stronger effects on manic episodes $(p<0.0001)$.

\section{Discussion}

We here performed a systematic review of the efficacy of LAI treatments in BD and SA; we rated our review according to the AMSTAR system and we found it to be of moderate quality (Shea et al., 2017). The present systematic review examined the efficacy of LAls for maintenance treatment of BD and SAD compared with PBO and oral medications. Regarding FGDAs, although there are not head-to-head comparisons between FGDAs and SGDAs, the trials reviewed indicate that there are some differences between these two AP groups. Depot Flup-D was the AP most investigated. There are only two controlled studies and they are negative. The PBO controlled study with Flup-D added to lithium and the comparison of Flup-D vs. lithium did not show differences in days of hospitalization, number of episodes/year and time spent ill (Ahlfors et al., 1981; Esparon et al., 1986). Moreover, the negative results of Esparon's et al. randomized trial (1986) might be due to the lack of effect on depression or a possible worsening of depression with FlupD compared to PBO, even if the more severe depression found in six of eight Flup-D-treated patients was not statistically significant. Overall, FGDAs might be as effective as lithium in preventing manic episodes, but without efficacy on depressive recurrences, and they might even worsen depressive symptoms. Limitations of FGDA studies include the lack of adequate sample sizes, comparators arms and outcome measures for mood disorders. Furthermore, their time-frame is different from those carried-out on SGDAs and this may impact multiple factors that might affect outcomes, including diagnostic modalities and study designs.

With respect to SGDAs, the most robust evidence is related to the use of RIS-LAl depot. RIS-LAI was found to be effective in preventing relapses of any mood symptoms (primary outcome) as well as for preventing manic symptoms compared to $\mathrm{PBO}$, including BD patients with rapid cycling in whom RIS-LAI resulted more effective compared also to oral medications (Macfadden et al., 2009; Martinez-Aran et al., 2009; Kishi et al., 2016).

Furthermore, the use of RIS-LAI improved CGI-S (Savas et al., 2006; Yatham et al., 2007; Vieta et al., 2008; Macfadden et al., 2009; Vieta et al., 2012) and YMRS scores (Yatham et al., 2007; Macfadden et al., 2009; Quiroz et al., 2010), decreased number of hospitalisations and the length of stay (Vieta et al., 2008, 2012; Peuskens et al., 2010; Hsieh et al., 2017), and reduced discontinuation rates of current treatments (Vieta et al., 2008; Quiroz et al., 2010) and hetero-aggressive episodes (Vieta et al., 2008). When the study was observational and other drugs could be used along RIS-LAI, (Vieta et al., 2008), about one third of patients were receiving or introduced lithium, while all patients were on anticonvulsants or lithium throughout the study; this could have affected outcome, hence studies are needed to evaluate the ability of each treatment alone or combined in preventing a bipolar mood episode.

Although RIS-LAl did not show an efficacy in preventing depressive recurrences, at the same time this drug did not worsen depressive symptoms as did the FGDAs (Esparon et al., 1986; Macfadden et al., 2009; Hsieh et al., 2017).

The only study assessing the efficacy of Pal-P in SAD patients showed the efficacy of this drug in preventing psychotic, depressive, and manic symptoms both in add-on or monotherapy and in improving and maintaining functioning beyond symptom control (Fu et al., 2015). Further studies are needed to assess the efficacy of Pal-P in the maintenance treatment of $\mathrm{BD}$, both in terms of manic and depressive relapses.

Similarly, the results of the study of Calabrese et al., (2017) investigating the efficacy of Ari-M in BD patients gave support to the FDA indication of this drug for the maintenance treatment of BD-I. In fact, in patients with BD-I who had a manic episode at study enrolment, Ari-M delayed the time to mood episode recurrence (primarily manic), without increasing depressive episodes.

Noteworthy, the predominantly antimanic vs. antidepressant preventive efficacy of LAls in BD is consistent with their polarity index (Popovic et al., 2012) and with their use in patients with poor treatment adherence. In fact, several studies found that factors that have been related with poor adherence in BD and SAD include a rapid cycling course, a greater illness severity (Martinez-Aran et al., 2009; Perlis et al., 2010), the predominance of manic symptoms and a higher rate of recurrences and hospitalisations, but not depressive symptoms (Sylvia et al., 2014). In this sense, LAls may represent an effective treatment strategy by increasing medication adherence and by reducing relapses in these subtypes of BD patients. To test the ability of LAl medications to supersede their oral counterparts in preventing mood episodes, study designs should focus on accurately assessing treatment adherence and clinical course in parallel groups receiving the same drug, one oral and the other LAl.

\subsection{Limitations}

The limitations of this review are the same of the studies it included, and include undisclosed intersite differences for the multisite trials, small sample sizes for the older LAl trials, inconsistent methodologies that prevented us from 
Table 2 Tentative indications for BD and SAD maintenance treatment with LAls.

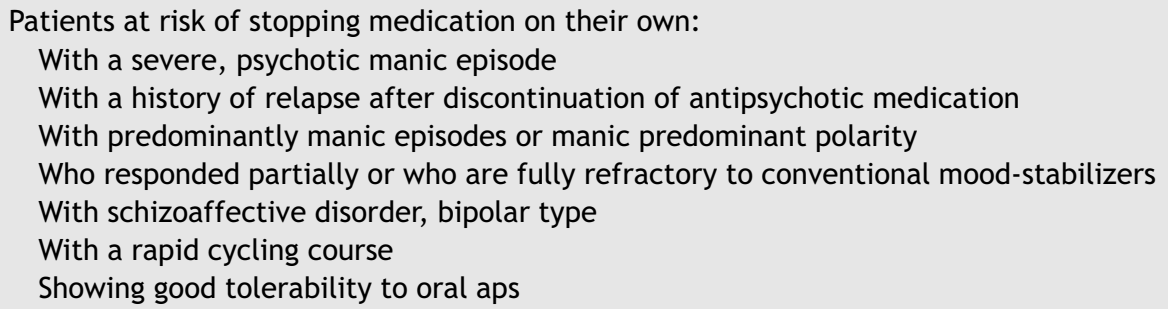

APs, antipsychotic drugs; BD, bipolar disorder; LAls, long-acting injectable antipsychotic drugs; SAD, schizoaffective disorder.

Table 3 Take-home messages for LAls used in BD and SAD.

\begin{tabular}{|c|c|c|c|}
\hline LAl drugs & Take-home message & Specific effects & Side effects \\
\hline Risperidone microspheres & $\begin{array}{l}\text { Needs to be administered } \\
\text { twice as often as paliperidone } \\
\text { palmitate }\end{array}$ & $\begin{array}{l}\text { Effective as antipsychotic, } \\
\text { highly selective on } D_{2} \text { receptors }\end{array}$ & $\begin{array}{l}\text { Galactorrhoea, } \\
\text { hyperprolactinaemia; } \\
\text { sometimes also } \\
\text { extrapyramidal side effects }\end{array}$ \\
\hline Olanzapine pamoate & $\begin{array}{l}\text { Gradually abandoned; Possible } \\
\text { advantage: May facilitate } \\
\text { antidepressant actions of } \mathrm{ADs}^{\mathrm{a}}\end{array}$ & $\begin{array}{l}\text { Effective as antipsychotic, } \\
\text { highly selective on } D_{2} \text { receptors }\end{array}$ & $\begin{array}{l}\text { Post-injection syndrome; } \\
\text { injection site reaction } \\
\text { frequent; metabolic } \\
\text { syndrome; obesity }\end{array}$ \\
\hline Paliperidone palmitate & $\begin{array}{l}\text { Tested in SAD, not in } \mathrm{BD} \text {; may } \\
\text { be less indicated for people } \\
\text { with SUD }{ }^{\mathrm{b}} \text {; Possible advantage: } \\
\text { Multiple dosages available }\end{array}$ & $\begin{array}{l}\text { Effective as antipsychotic, } \\
\text { highly selective on } D_{2} \text { receptors }\end{array}$ & $\begin{array}{l}\text { Galactorrhoea, } \\
\text { hyperprolactinaemia; } \\
\text { sometimes also } \\
\text { extrapyramidal side effects }\end{array}$ \\
\hline Aripiprazole monohydrate & $\begin{array}{l}\text { Advantages: Effective in } \mathrm{BD} \text {; } \\
\text { large effects on } \mathrm{QoL}^{\mathrm{b}} \text {; } \\
\text { Disadvantage: Needs oral } \\
\text { supplementation at initiation }\end{array}$ & $\begin{array}{l}\text { Allows better prefrontal } \\
\text { function thanks to partial } \\
\text { agonism on } D_{2} \text { receptors }\end{array}$ & Akathisia \\
\hline Aripiprazole lauroxil & $\begin{array}{l}\text { Not yet tested in BD or } \\
\text { specifically in SAD; Possible } \\
\text { advantage: Longer intervals of } \\
\text { administration, multiple dosing }\end{array}$ & $\begin{array}{l}\text { Allows better prefrontal } \\
\text { function thanks to partial } \\
\text { agonism on } D_{2} \text { receptors }\end{array}$ & Akathisia \\
\hline
\end{tabular}

performing a meta-analysis, and generally medium level of evidence. A comparison between LAls and first generation depot neuroleptics is not feasible, since the older published studies lacked scientific rigour.

Summarizing, the level of evidence for the use of LAls in the maintenance treatment of BD and SAD is still limited, since there are only a few large, controlled, randomised trials in the literature, but there are several clinical scenarios in which they may be a first-line option, with the exception of FGDAs, due to the risk of inducing depression. Examining the use of SGDAs, evidence reviewed on RIS-LAl suggests that this drug is effective as maintenance treatment in BD and SAD and in improving adherence to medication in these patients, through the efficacy on manic recurrences, without worsening depression. Similarly promising results have been found with Pal-P in SAD patients and with Ari-M in BD patients. Tentative indications for the use of LAls in BD and SAD are shown in Table 2.

Further studies are needed on the use of LAls in BD and $S A D$, especially assessing the newest drugs such as paliperidone and aripiprazole in special populations of BD patients, i.e. those with rapid cycling or with high numbers of manic relapses, in order to improve treatment adherence and the clinical course of BD. Moreover, the long-term impact of those compounds on cognitive and functional outcomes, which are heavily influenced by the number of manic recurrences (Sanchez-Moreno et al., 2018), should be addressed. Future studies should also focus on site of injection (deltoid vs. gluteal) (Heres et al., 2012) and timing of administration (twice vs. once-monthly vs. three-month), as well as on less invasive methods of drug level monitoring (Murru et al., 2017). 3-Month paliperidone has advantages and disadvantages over once-monthly injections, and so may prove to have aripiprazole lauroxil with its two-month option, although it has not as yet been tested in BD. We await studies with these novel LAl formulations to gain a complete picture of LAls in the treatment of BD and SAD. Furthermore, the concomitant use of LAl antipsychotics and mood stabilizers should be adequately assessed like in Macfadden et al. (2009), as there is preliminary evidence 
that oral SGA antipsychotic add-on might protect against manic relapses/recurrences in BD.

Another issue needing clarification is whether side effects related to LAls tend to be "long-acting" as their formulation. There always has been concern among clinicians as to this aspect, but reassuring data as to the similarity with the side effects observed with oral antipsychotics has been gathered over the years, with patients gradually adapting to these side effects (Knudsen et al., 1985; Marder, 1986). Although in one study LAls compared favourably to their oral counterparts for what concerns side effects (Sağlam Aykut et al., 2017), there are still concerns regarding their dosing and availability (Taylor, 2009), as well as suicide risk (Gentile, 2013), that should be addressed by future studies.

In conclusion, we provide a take-home series of messages in Table 3, including each LAl's specific actions and side effects that may limit their application in patients with bipolar or schizoaffective disorder.

\section{Role of funding source}

This work was supported with funding from the Spanish Ministry of Science, Innovation and Universities, the Centro de Investigación en Red de Salud Mental, CIBERSAM, the Instituto de Salud Carlos III through a "Río Hortega" contract (CM17/00258) to NV, Recerca del DIUE de la Generalitat de Catalunya to the Bipolar Disorders Group (2017-SGR-01365).

\section{Contributors}

Drs. Pacchiarotti and Vieta conceived the review and provided indications for the design; Drs. Pacchiarotti and Kotzalidis designed the searches and conducted them, identified relevant literature and wrote the first drafts of the paper; Drs. Tiihonen, Verdolini, Murru, Goikolea, Valentí, and Aedo contributed in writing substantial portions of the manuscript; Prof. Vieta reviewed the final draft; all authors participated in Delphi rounds to reach consensus about study inclusion and approved the final version of the manuscript.

\section{Conflict of interest}

Dr. Pacchiarotti has received CME-related honoraria, or consulting fees from ADAMED, Janssen-Cilag, and Lundbeck

Dr. Tiihonen reported serving as a consultant to AstraZeneca, Bristol- Myers Squibb, Eli Lilly, F. HoffmanLa Roche, Janssen-Cilag, Lundbeck, Organon, and Finnish Medicines Agency; receiving fees for giving expert testimony to AstraZeneca, Bristol-Myers Squibb, Eli Lilly, GlaxoSmithKline, Janssen-Cilag, Lundbeck, Otsuka, and Pfizer; receiving lecture fees from AstraZeneca, Bristol-Myers Squibb, Eli Lilly, GlaxoSmithKline, Janssen-Cilag, Lundbeck, Novartis, Otsuka, and Pfizer; receiving grants from Stanley Foundation and Sigrid Jusélius Foundation; serving as a member of advisory boards for AstraZeneca, Eli Lilly, Janssen-Cilag, and Otsuka; and having research collaboration with Lilly and Janssen-Cilag.
Dr. Kotzalidis has no conflicts of interest.

Dr. Verdolini is funded by the Spanish Ministry of Economy and Competitiveness, Instituto de Salud Carlos III through a "Río Hortega" contract (CM17/00258) and reports no financial or other relationship relevant to the subject of this article.

Dr. Murru has no conflicts of interest.

Dr. Goikolea has been a speaker or on the advisory board for Astra-Zeneca, BristolMyers-Squibb, Eli Lilly, Glaxo-Smith-Kline, Janssen-Cilag,Merck Sharpe and Dohme, Otsuka, Pfizer, Sanofi-Aventis.

Dr. Valentí has received grants from Eli Lilly \& Co.; and has served as a speaker for Abbott, Bristol-Myers Squibb, GlaxoSmithKline, and Janssen-Cilag.

Dr. Aedo has no conflicts of interest.

Prof. Eduard Vieta has received research support from or served as consultant, adviser or speaker for AB-Biotics, Actavis, Allergan, Angelini, AstraZeneca, Bristol-Myers Squibb, Dainippon Sumitomo Pharma, Ferrer, Forest Research Institute, Gedeon Richter, Glaxo-Smith-Kline, Janssen, Lundbeck, Otsuka, Pfizer, Roche, Sanofi-Aventis, Servier, Shire, Sunovion, Takeda, Telefónica, the Brain and Behaviour Foundation, the Spanish Ministry of Science and Innovation (CIBERSAM), the Seventh European Framework Programme (ENBREC), and the Stanley Medical Research Institute and reports no financial or other relationship relevant to the subject of this article.

\section{Acknowledgments}

The authors thank the support of the Spanish Ministry of Science, Innovation and Universities integrated into the Plan Nacional de I+D+I and co-financed by the ISCIIISubdirección General de Evaluación and the Fondo Europeo de Desarrollo Regional (FEDER); the Instituto de Salud Carlos III that supported this work through a "Río Hortega" contract (CM17/00258 to NV); the CIBERSAM (Centro de Investigación Biomédica en Red de Salud Mental); the Secretaria d'Universitats i Recerca del Departament d'Economia i Coneixement (2017-SGR-01365) and the CERCA Programme / Generalitat de Catalunya.

\section{Supplementary materials}

Supplementary material associated with this article can be found, in the online version, at doi:10.1016/j.euroneuro. 2019.02.003.

\section{References}

Ahlfors, U.G., Baastrup, P.C., Dencker, S.J., Elgen, K., Lingjaerde, O., Pedersen, V., Schou, M., Aaskoven, O., 1981. Flupenthixol decanoate in recurrent manic-depressive illness. A comparison with lithium. Acta Psychiatr. Scand. 64 (3), 226-237.

Argolo, L., Batista, F., Bezerra-Filho, S., Kapczinski, F., MirandaScippa, Â, 2018. Case series of diagnostic shift from bipolar disorder to schizoaffective disorder. Nord. J. Psychiatry 72 (3), 232235. doi:10.1080/08039488.2017.1411524, Epub 2017 Nov 30.

Bobo, W.V., Epstein, R.A., Lynch, A., Patton, T.D., Bossaller, N.A., Shelton, R.C., 2011. A randomized open comparison of long- 
acting injectable risperidone and treatment as usual for prevention of relapse, rehospitalization, and urgent care referral in community-treated patients with rapid cycling bipolar disorder. Clin. Neuropharmacol. 34 (6), 224-233. doi:10.1097/WNF. 0b013e318237709a.

Bortolato, B., Miskowiak, K.W., Köhler, C.A., Vieta, E., Carvalho, A.F., 2015. Cognitive dysfunction in bipolar disorder and schizophrenia: a systematic review of meta-analyses. Neuropsychiatr. Dis. Treat. 11, 3111-3125. doi:10.2147/NDT. S76700.

Calabrese, J.R., Sanchez, R., Jin, N., Amatniek, J., Cox, K., Johnson, B., Perry, P.P., Hertel, P., Such, P., McQuade, R.D., Nyilas, M., Carson, W.H., 2017. Efficacy and safety of aripiprazole once-monthly in the maintenance treatment of bipolar I disorder: a double-blind, placebo-controlled, 52-week randomized withdrawal study. J. Clin. Psychiatry 78 (3), 324-331. doi:10.4088/JCP.14m09416.

Chan, H.W., Huang, C.Y., Feng, W.J., Yen, Y.C., 2016. Clinical outcomes of long-acting injectable risperidone in patients with bipolar I disorder: a 1-year retrospective cohort study. J. Affect. Disord. 205, 360-364. doi:10.1016/j.jad.2016.08.023

Chengappa, K.N., Turkin, S.R., Schlicht, P.J., Murphy, S.L., Brar, J.S., Fagiolini, A., Houck, P.R., Garbutt, R.G., Fredrick, N., 2010. A Pilot, 15-month, randomised effectiveness trial of Risperidone long acting injection (RLAl) versus oral atypical antipsychotic agents (AAP) in persons with bipolar disorder. Acta Neuropsychiatr. 22 (2), 68-80. doi:10.1111/j.1601-5215.2010. 00458.x.

Colom, F., Vieta, E., Martínez-Arán, A., Reinares, M., Benabarre, A., Gastó, C., 2000. Clinical factors associated with treatment noncompliance in euthymic bipolar patients. J. Clin. Psychiatry 61 (8), 549-555.

Correll, C.U., Citrome, L., Haddad, P.M., Lauriello, J., Olfson, M., Calloway, S.M., Kane, J.M., 2016. The use of long-acting injectable antipsychotics in schizophrenia: evaluating the evidence. J. Clin. Psychiatry 77 (suppl 3), 1-24. doi:10.4088/JCP. 15032su1.

Cuomo, I., Kotzalidis, G.D., de Persis, S., Piacentino, D., Perrini, F., Amici, E., De Filippis, S., 2018. Head-to-head comparison of 1-year aripiprazole long-acting injectable (LAI) versus paliperidone LAI in comorbid psychosis and substance use disorder: impact on clinical status, substance craving, and quality of life. Neuropsychiatr. Dis. Treat. 14, 1645-1656. doi:10.2147/ NDT.S171002.

Derry, S., Moore, R.A., 2007. Atypical antipsychotics in bipolar disorder: systematic review of randomised trials. BMC Psychiatry 7, 40.

Esparon, J., Kolloori, J., Naylor, G.J., McHarg, A.M., Smith, A.H., Hopwood, S.E., 1986. Comparison of the prophylactic action of flupenthixol with placebo in lithium treated manic-depressive patients. Br. J. Psychiatry 148, 723-725.

Fu, D.-J., Turkoz, I., Simonson, R.B., Walling, D.P., Schooler, N.R., Lindenmayer, J.P., Canuso, C.M., Alphs, L., 2015. Paliperidone palmitate once-monthly reduces risk of relapse of psychotic, depressive, and manic symptoms and maintains functioning in a double-blind, randomized study of schizoaffective disorder. J. Clin. Psychiatry 76 (3), 253-262.

Gentile, S., 2013. Adverse effects associated with secondgeneration antipsychotic long-acting injection treatment: a comprehensive systematic review. Pharmacotherapy 33 (10), 1087-1106. doi:10.1002/phar.1313.

Gigante, A.D., Lafer, B., Yatham, L.N., 2012. Long-acting injectable antipsychotics for the maintenance treatment of bipolar disorder. CNS Drugs 26 (5), 403-420. doi:10.2165/ 11631310-000000000-00000.

Goodwin, G.M.Consensus Group of the British Association for Psychopharmacology, 2009. Evidence-based guidelines for treating bipolar disorder: revised second edition-recommendations from the British Association for Psychopharmacology. J. Psychopharmacol. 23 (4), 346-388. doi:10.1177/0269881109102919.

Grande, I., Berk, M., Birmaher, B., Vieta, E., 2016. Bipolar disorder. Lancet 387, 1561-1572. doi:10.1016/S0140-6736(15)00241-X.

Grunze, H., Vieta, E., Goodwin, G.M., 2013. The World Federation of Societies of Biological Psychiatry (WFSBP) Guidelines for the Biological Treatment of Bipolar Disorders: update 2012 on the long-term treatment of bipolar disorder. World J. Biol. Psychiatry 14, 154-219.

Hamann, J., Kissling, W., Heres, S., 2014. Checking the plausibility of psychiatrists' arguments for not prescribing depot medication. Eur. Neuropsychopharmacol. 24 (9), 1506-1510. doi:10. 1016/j.euroneuro.2014.06.015.

Heres, S., Frobose, T., Hamann, J., Leucht, S., Maino, K., Reichhart, T., Stiegler, M., Kissling, W., 2012. Patients' acceptance of the deltoid application of risperidone long-acting injection. Eur. Neuropsychopharmacol. 22 (12), 897-901. doi:10.1016/j. euroneuro.2012.04.014.

Higgins, J.P.T., Green, S., 2011. Cochrane Handbook for Systematic Reviews of Interventions Version 5.1.0. The Cochrane Collaboration, London, UK [updated March 2011]Available from www. handbook.cochrane.org

Hsieh, M.H., Chuang, P.Y., Wu, C.S., Chang, C.J., Chung, P.F., Tang, C.H., 2017. Bipolar patients treated with long-acting injectable risperidone in Taiwan: a 1-year mirror-image study using a national claims database. J. Affect. Disord. 218, 327-334. doi:10.1016/j.jad.2017.04.074.

Jadad, A.R., Moore, R.A., Carroll, D., Jenkinson, C., Reynolds, D.J., Gavaghan, D.J., McQuay, H.J., 1996. Assessing the quality of reports of randomized clinical trials: is blinding necessary? Control. Clin. Trials 17, 1-12.

Kendall, T., Morriss, R., Mayo-Wilson, E., Marcus, E.Guideline Development Group of the National Institute for Health and Care Excellence, 2014. Assessment and management of bipolar disorder: summary of updated NICE guidance. B.M.J. 349, g5673.

Kishi, T., Oya, K., Iwata, N., 2016. Long-acting injectable antipsychotics for prevention of relapse in bipolar disorder: a systematic review and meta-analyses of randomized controlled trials. Int. J. Neuropsychopharmacol. 19 (9). doi:10.1093/ijnp/ pyw038, pii: pyw038.

Knudsen, P., Hansen, L.B., Højholdt, K., Larsen, N.E., 1985. Long-term depot neuroleptic treatment with perphenazine decanoate. I. Efficacy and side effects in a 12 month study of 42 drug monitored psychotic patients. Acta Psychiatr. Scand. 72 (Suppl. 322), 29-40.

Lähteenvuo, M., Tanskanen, A., Taipale, H., Hoti, F., Vattulainen, P., Vieta, E., Tiihonen, J., 2018. Real-world effectiveness of pharmacologic treatments for the prevention of rehospitalization in a Finnish nationwide cohort of patients with bipolar disorder. JAMA Psychiatry 75 (4), 347-355. doi:10.1001/ jamapsychiatry.2017.4711.

Lindenmayer, J.P., Khan, A., Eerdekens, M., Van Hove, I., Kushner, S., 2007. Long-term safety and tolerability of long-acting injectable risperidone in patients with schizophrenia or schizoaffective disorder. Eur. Neuropsychopharmacol. 17 (2), 138-144.

Llorca, P.M., Abbar, M., Courtet, P., Guillaume, S., Lancrenon, S., Samalin, L., 2013. Guidelines for the use and management of long-acting injectable antipsychotics in serious mental illness. BMC Psychiatry 13, 340. doi:10.1186/1471-244X-13-340.

Macfadden, W., Alphs, L., Haskins, J.T., Turner, N., Turkoz, I., Bossie, C., Kujawa, M., Mahmoud, R., 2009. A randomized, double-blind, placebo-controlled study of maintenance treatment with adjunctive risperidone long-acting therapy in patients with bipolar I disorder who relapse frequently. Bipolar Disord. 11 (8), 827-839. doi:10.1111/j.1399-5618.2009.00761.x.

Martinez-Aran, A., Scott, J., Colom, F., Torrent, C., TabaresSeisdedos, R., Daban, C., Leboyer, M., Henry, C., Goodwin, G.M., Gonzalez-Pinto, A., Cruz, N., Sanchez-Moreno, J., 
Vieta, E., 2009. Treatment nonadherence and neurocognitive impairment in bipolar disorder. J. Clin. Psychiatry 70 (7), 10171023. doi: $10.4088 /$ JCP.08m04408.

Marder, S.R., 1986. Depot neuroleptics: side effects and safety. J. Clin. Psychopharmacol. 6 (1 Suppl.), 24S-29S.

Miller, S.A., 2001. PICO Worksheet and Search Strategy National Center for Dental Hygiene Research. University of Southern California, Los Angeles.

Moher, D., Liberati, A., Tetzlaff, J., Altman, D.G.PRISMA Group., 2009. The PRISMA Group. Preferred reporting items for systematic reviews and meta-analyses: the PRISMA statement. PLOS Med. 6, e1000097. doi:10.1371/journal.pmed.1000097, Epub 2009 Jul 21.

Murru, A., Pacchiarotti, I., Nivoli, A.M., Bonnin, C.M., Patrizi, B., Amann, B., Vieta, E., Colom, F., 2012. Rates and clinical correlates of treatment non-adherence in schizoaffective bipolar patients. Acta Psychiatr. Scand. 125 (5), 412-418. doi:10.1111/ j.1600-0447.2012.01837.x.

Murru, A., Pacchiarotti, I., Amann, B.L., Nivoli, A.M., Vieta, E., Colom, F., 2013. Treatment adherence in bipolar I and schizoaffective disorder, bipolar type. J. Affect. Disord. 151, 1003-1008. doi:10.1016/j.jad.2013.08.026.

Murru, A., Manchia, M., Tusconi, M., Carpiniello, B., Carpiniello, B., Pacchiarotti, I., Colom, F., Vieta, E., 2016. Diagnostic reliability in schizoaffective disorder. Bipolar Disord 18 (1), 78-80. doi:10. $1111 /$ bdi.12366.

Murru, A., Torra, M., Callari, A., Pacchiarotti, I., Romero, S., Gonzalez de la Presa, B., Varo, C., Goikolea, J.M., Pérez-Sola, V., Vieta, E., Colom, F., 2017. A study on the bioequivalence of lithium and valproate salivary and blood levels in the treatment of bipolar disorder. Eur. Neuropsychopharmacol. 27 (8), 744-750. doi:10.1016/j.euroneuro.2017.06.003.

National Collaborating Centre for Mental Health (UK), 2018. Bipolar Disorder: The NICE Guideline on the Assessment and Management of Bipolar Disorder in Adults, Children and Young People in Primary and Secondary Care. British Psychological Society, Leicester (UK).

National Health and Medical Research Council (NHMRC) of the Australian Government, 2009. NHMRC Levels of Evidence and Grades For Recommendations for Developers of Guidelines. National Health and Medical Research Council, Canberra, ACT, Australia.

Nivoli, A.M., Murru, A., Vieta, E., 2010. Lithium: still a cornerstone in the long-term treatment in bipolar disorder? Neuropsychobiology 62 (1), 27-35. doi:10.1159/000314307.

Perlis, R.H., Ostacher, M.J., Miklowitz, D.J., Hay, A., Nierenberg, A.A., Thase, M.E., Sachs, G.S., 2010. Clinical features associated with poor pharmacologic adherence in bipolar disorder: results from the STEP-BD study. J. Clin. Psychiatry 71 (3), 296303. doi: $10.4088 /$ JCP.09m05514yel.

Peuskens, J., Olivares, J.M., Pecenak, J., Tuma, I., Bij de Weg, H., Eriksson, L., Resseler, S., Akhras, K., Jacobs, A., 2010. Treatment retention with risperidone long-acting injection: 24-month results from the Electronic Schizophrenia Treatment Adherence Registry (e-STAR) in six countries. Curr. Med. Res. Opin. 26 (3), 501-509. doi:10.1185/03007990903488670.

Popovic, D., Reinares, M., Goikolea, J.M., Bonnin, C.M., GonzalezPinto, A., Vieta, E., 2012. Polarity index of pharmacological agents used for maintenance treatment of bipolar disorder. Eur. Neuropsychopharmacol. 22 (5), 339-346. doi:10.1016/j. euroneuro.2011.09.008.

Quiroz, J.A., Yatham, L.N., Palumbo, J.M., Karcher, K., Kushner, S., Kusumakar, V., 2010. Risperidone long-acting injectable monotherapy in the maintenance treatment of bipolar I disorder. Biol. Psychiatry 68 (2), 156-162. doi:10.1016/j.biopsych. 2010.01.015.
Samalin, L., Nourry, A., Charpeaud, T., Llorca, P.M., 2014. What is the evidence for the use of second-generation antipsychotic long-acting injectables as maintenance treatment in bipolar disorder? Nord. J. Psychiatry 68, 227-235.

Sanchez-Moreno, J., Bonnin, C.M., González-Pinto, A., Amann, B.L., Solé, B., Balanzá-Martinez, V., Arango, C., Jiménez, E., Tabarés-Seisdedos, R., Garcia-Portilla, M.P., Ibáñez, A., Crespo, J.M., Ayuso-Mateos, J.L., MartinezAran, A., Torrent, C., Vieta, E.CIBERSAM Functional Remediation Group, 2018. Factors associated with poor functional outcome in bipolar disorder: sociodemographic, clinical, and neurocognitive variables. Acta Psychiatr. Scand. (May 3) doi:10.1111/acps.12894.

Sağlam Aykut, D., Civil Arslan, F., Tiryaki, A., Özkorumak, E., Karakullukçu, S., 2017. Ikinci kușak antipsikotik kullanan hastalarda ilaç yan etkileri ve yașam kalitesi: uzun etkili enjeksiyon ve ağızdan alınan tedavilerin karșılaștırılması [Adverse effects of medication and quality of life in patients receiving second generation antipsychotics: a comparison of long acting injectable and oral therapies-Turkish]. Türk. Psikiyatri Derg. 28 (1), 11-16.

Savas, H.A., Yumru, M., Ozen, M.E., 2006. Use of long-acting risperidone in the treatment of bipolar patients. J. Clin. Psychopharmacol. 26 (5), 530-531.

Shea, B.J., Reeves, B.C., Wells, G., Thuku, M., Hamel, C., Moran, J., Moher, D., Tugwell, P., Welch, V., Kristjansson, E., Henry, D.A., 2017. AMSTAR 2: a critical appraisal tool for systematic reviews that include randomised or non-randomised studies of healthcare interventions, or both. B.M.J. 358, j4008.

Solé, B., Bonnin, C.M., Jiménez, E., Torrent, C., Torres, I., Varo, C., Valls, E., Montejo, L., Gómez-Ocaña, C., Tomioka, Y., Vieta, E., Martinez-Aran, A., Reinares, M., 2018. Heterogeneity of functional outcomes in patients with bipolar disorder: a clusteranalytic approach. Acta Psychiatr. Scand. 137 (6), 516-527. doi:10.1111/acps.12871, Epub 2018 Mar 5.

Sylvia, L.G., Reilly-Harrington, N.A., Leon, A.C., Kansky, C.I., Calabrese, J.R., Bowden, C.L., Ketter, T.A., Friedman, E.S., losifescu, D.V., Thase, M.E., Ostacher, M.J., Keyes, M., Rabideau, D., Nierenberg, A.A., 2014. Medication adherence in a comparative effectiveness trial for bipolar disorder. Acta Psychiatr. Scand. 129 (5), 359-365. doi:10.1111/acps.12202.

Taylor, D., 2009. Psychopharmacology and adverse effects of antipsychotic long-acting injections: a review. Br. J. Psychiatry 195 (Suppl. 52), S13-S19. doi:10.1192/bjp.195.52.s13.

Tohen, M., Vieta, E., Calabrese, J., Ketter, T.A., Sachs, G., Bowden, C., Mitchell, P.B., Centorrino, F., Risser, R., Baker, R.W., Evans, A.R., Beymer, K., Dube, S., Tollefson, G.D., Breier, A., 2003. Efficacy of olanzapine and olanzapine-fluoxetine combination in the treatment of bipolar I depression. Arch Gen. Psychiatry 60 (11), 1079-1088 errata corrige, Arch. Gen. Psychiatry 2004, 61(2), 176.

Tondo, L., Vázquez, G.H., Baethge, C., Baronessa, C., Bolzani, L., Koukopoulos, A., Mazzarini, L., Murru, A., Pacchiarotti, I., Pinna, M., Salvatore, P., Sani, G., Selle, V., Spalletta, G., Girardi, P., Tohen, M., Vieta, E., Baldessarini, R.J., 2016. Comparison of psychotic bipolar disorder, schizoaffective disorder, and schizophrenia: an international, multisite study. Acta Psychiatr. Scand. 133 (1), 34-43. doi:10.1111/acps.12447.

Vieta, E., Nieto, E., Autet, A., Rosa, A.R., Goikolea, J.M., Cruz, N., Bonet, P., 2008. A long-term prospective study on the outcome of bipolar patients treated with long-acting injectable risperidone. World J. Biol. Psychiatry 9 (3), 219-224. doi:10.1080/ 15622970701530917.

Vieta, E., Montgomery, S., Sulaiman, A.H., Cordoba, R., Huberlant, B., Martinez, L., Schreiner, A., 2012. A randomized, double-blind, placebo-controlled trial to assess prevention of mood episodes with risperidone long-acting injectable in 
patients with bipolar I disorder. Eur. Neuropsychopharmacol. 22 (11), 825-835. doi:10.1016/j.euroneuro.2012.03.004, Epub 2012 Apr 12.

Vieta, E., Berk, M., Schulze, T.G., Carvalho, A.F., Suppes, T., Calabrese, J.R., Gao, K., Miskowiak, K.W., Grande, I., 2018. Bipolar disorders. Nat. Rev. Dis. Primers 4, 18008. doi:10.1038/nrdp. 2018.8.

Yatham, L.N., Fallu, A., Binder, C.E., 2007. A 6-month randomized open-label comparison of continuation of oral atypical antipsychotic therapy or switch to long acting injectable risperidone in patients with bipolar disorder. Acta Psychiatr. Scand. 116 (Suppl. 434), 50-56.
Yatham, L.N., Kennedy, S.H., Parikh, S.V., Schaffer, A., Bond, D.J., Frey, B.N., Sharma, V., Goldstein, B.I., Rej, S., Beaulieu, S., Alda, M., MacQueen, G., Milev, R.V., Ravindran, A., O’Donovan, C., McIntosh, D., Lam, R.W., Vazquez, G., Kapczinski, F., McIntyre, R.S., Kozicky, J., Kanba, S., Lafer, B., Suppes, T., Calabrese, J.R., Vieta, E., Malhi, G., Post, R.M., Berk, M., 2018. Canadian Network for Mood and Anxiety Treatments (CANMAT) and International Society for Bipolar Disorders (ISBD) 2018 guidelines for the management of patients with bipolar disorder. Bipolar Disord. 20, 97-170. doi:10.1111/bdi.12609. 